\title{
RECOGNITION OF A PATENT AS INVALID IN THE FEDERAL PATENT COURT OF GERMANY AS A SUBJECT OF RESEARCH IN THE EDUCATIONAL PROCESS IN THE DIRECTION OF “JURISPRUDENCE”
}

\author{
Karina Kirilova $^{1 *}$, Andrey Kirilov ${ }^{2}$ \\ ${ }^{1}$ Post-graduate student of the Department of Judicial Power, Law Enforcement and Human Rights \\ Activities, RUDN, Russia, kbodyanchuk@mail.ru \\ ${ }^{2} \mathrm{PhD}$ in Law, Advisor to the Control Department of the State Corporation Fund for the Promotion of \\ Housing and Communal Services Reform, Russia, askirilov@gmail.com \\ ${ }^{*}$ Corresponding author
}

\begin{abstract}
By including the study of foreign law in the educational program of the Russian Federation, the developers help future specialists to study various areas that can be used by them in their future work. In our opinion, the study of the patent law of Germany and other countries, as well as the study of the protection of such a right in a judicial body at Russian universities, takes place in order to familiarize students with the legal system of other states. Students using a comparative analysis of the judicial system of the Russian Federation and other countries, for example Germany, determine the similarities and differences between the two legal systems. For example, the Federal Patent Court of Germany has been the highest Federal Court since 1961 and has the status of a specialized court (studying the competence and tasks of this judicial body, students conduct a comparative analysis with the functions of the Intellectual Property Rights Court of the Russian Federation). One of the powers of the court is to invalidate a registered patent. This procedure is complex and lengthy, which is why this topic is included in the list of educational programs in the direction of "jurisprudence". Our work is devoted to the analysis of the judicial process for the recognition of a patent as invalid. The authors consider the procedure of legal proceedings in the Federal Patent Court of Germany from filing a lawsuit to the court to the decision made by the Senate. On claims for invalidation of registered patents, he makes decisions of the court of first instance. The authors pay special attention to the relationship between the lawsuit on patent infringement and the lawsuit on invalidation of the patent. It should be noted that the Federal Patent Court of Germany is not an isolated structure from the judicial system (its decisions can be appealed to higher authorities), but, despite this, claims for patent invalidity and claims for patent infringement are considered in different judicial bodies. Thus, persons interested in invalidating a patent must first go through the process of recognizing patent infringement in a lower instance, since the powers of the patent court do not include consideration of claims for patent infringement. On the one hand, such a method of dividing proceedings on challenging the validity of a patent and infringement of an exclusive right reduces the risk of combining arguments on these categories of disputes, and on the other hand, such a feature of patent proceedings presents significant inconveniences for persons participating in this litigation. The results of the study can be implemented in the educational processes of higher educational institutions, which will reduce errors in making decisions and reduce the number of disputes arising with the validity and invalidity of patents.
\end{abstract}

Keywords: education in the Russian Federation, an educational program in the direction of "jurisprudence", German Federal Patent Court, specialized court, invalidity of patents, judicial process, intellectual property rights protection in Germany, principles of patent litigation, German Patent Law. 


\section{INTRODUCTION}

To date, the educational program of higher educational institutions includes the study of the procedure for invalidating a patent in the Federal Republic of Germany, which takes place in the Federal Patent Court. Students study and become familiar with the judicial process, competence and tasks of this judicial body.

In the Federal Patent Court, the judicial process is mainly based on the provisions of the regulatory legal act on patents, utility models, protection of integrated circuits, industrial designs, trademarks and new plant varieties $^{1}$. Additional norms that the court uses in court proceedings are the provisions of the Law on the Judicial System of the Federal Republic of Germany, as well as the Civil Procedure Code of the Federal Republic of Germany. The main feature of the application of the additional provisions is the determination by the court of the specifics of patent proceedings ${ }^{2}$.

The Federal Patent Court has the principle of initiating legal proceedings on the basis of a complaint, the principle of dispositivity, as well as the principle of formality.

The first principle implies that the trial is initiated as a result of the filing of an application by one of the participants. The submitted application specifies the subject of the proceedings. That is, the court in this case is not the initiator of the initiation of legal proceedings.

The second principle emerges from the possibility of the participants in the process to complete the trial by rejecting the application. The withdrawal of a protest is an isolated case in which the proceedings are terminated only for the person who withdrew the protest, and the case itself continues to be considered by the court ${ }^{3}$.

The principle of formality in patent proceedings consists in an objective clarification of all the circumstances of the case. If we compare this principle with the principle of competition, which operates in civil proceedings, then in the first case, in addition to the facts stated by the parties, the court investigates the circumstances that have arisen during the consideration of the case within the limits of the submitted application ${ }^{4}$. The parties are required to provide reliable information regarding the actual circumstances 5 .

German legislation does not contain provisions on the mandatory involvement of lawyers or patent attorneys in the judicial process in the Federal Patent Court. Thus, participants can, at their own request, either involve lawyers, or build their own defense on their own. In some cases, both an individual and a legal entity may act as an authorized representative. An exception is the case when the participant in the process does not have a permanent place of residence on the territory of Germany. In such a situation the party is represented in court by a lawyer or a patent attorney ${ }^{6}$. The bar, as rightly noted by I.I. Belozerova, being a public institution, is in constant development. It is for this reason that the issue of the legal status of lawyers is particularly relevant. The most interesting thing is how the legal status of a lawyer has changed over time in different countries. Including in Germany (Belozerova, 2017, p. 48).

A lawyer and patent attorney may be a person who has the citizenship of an EU member State or States parties to the Agreement on the Common Economic Space.

The patent attorney has a technical education and also has special training in the field of intellectual property. It is easier for lawyers or patent attorneys to build defense tactics in the Federal Patent Court than to represent interests in the land court. The judges of the Federal Patent Court are highly qualified in technical matters, as they have a higher technical education. In civil courts, judges have a legal education,

\footnotetext{
${ }^{1} \S 66$. The Law on Trademarks of October 25, 1994 (Bulletin of Federal Laws I p. 3082; 1995 I p. 156; 1996 I p. 682), which was last amended by Article 11 of the Law of July 17, 2017. (Bulletin of Federal Laws I p. 2541) https://wipolex.wipo.int/ru/text/474281 (date of application 28.08.2021)

${ }^{2} \S 73$. The Patent Act of the Federal Republic of Germany (Patentgesetz - PatG) of December 16, 1980, which entered into force on January 1, 1981 with amendments and additions 1986, 1990, 1991, 1992, 1993, 1994,1995 gg http://www.gesetze-im-internet.de/ (date of application 25.08.2021)

${ }^{3} \S 61$. The Patent Act of the Federal Republic of Germany (Patentgesetz - PatG) of December 16, 1980, which entered into force on January 1, 1981 with amendments and additions 1986, 1990, 1991, 1992, 1993, 1994,1995 gg http://www.gesetze-im-internet.de/ (date of application 25.08.2021)

${ }^{4} \S 23$. The Law on the Protection of New Plant Varieties of the Federal Republic of Germany (as amended by the Law of 13.4.2017) https://wipolex.wipo.int/ru/text/461664 (date of application 28.08.2021)

${ }^{5} \S 124$. The Patent Act of the Federal Republic of Germany (Patentgesetz - PatG) of December 16, 1980, which entered into force on January 1, 1981 with amendments and additions 1986, 1990, 1991, 1992, 1993, 1994,1995 gg http://www.gesetze-im-internet.de/ (date of application 25.08.2021)

$6 \S \S 155,156,177,178,182$. The Code on Patent Attorneys (as amended by the Law of 30.10.2017) https://wipolex.wipo.int/ru/text/462228 (date of application 28.08.2021)
} 
which complicates the process of explaining technical issues. The lawyer's/patent attorney's fee depends on the amount of the claim (Stefan, Tkachev, 2013, p. 43).

\section{CONSIDERATION OF CASES IN THE FEDERAL PATENT COURT}

\subsection{Consideration of the Case}

Let's study in more detail the procedure for considering cases in the Federal Patent Court.

In order for the court to begin considering the case, the interested party, first of all, must file a claim or appeal to the judicial authority. Upon receipt of the document by the German Federal Patent Court, the claim/appeal is assigned a number. Then the document goes to the Senate, which is authorized to consider this issue.

The Federal Patent Court has a senate for validity cases and a Senate for complaints (Perun, 2014, p. 2).

The Senate on Validity Cases in most cases establishes the fact of invalidity of the patent in the form of oral proceedings, with the exception of some cases, which we will discuss below.

The Senate for the Consideration of Complaints mostly makes its decisions exclusively in writing, bypassing oral proceedings, but there are several cases where oral proceedings are conducted.

The first case is the initiative of the participant in the process.

The second case is the fact of insufficient evidence provided.

The third is the initiative of the court in connection with the need for more detailed proceedings in the interests of the case.

The decisions of the senates on the consideration of complaints are made in the form of resolutions. By a court decision, a preliminary hearing is held to discuss procedural issues.

After filing a claim/complaint to the court, each party has the right to express its position and state the arguments that it considers to be fundamentally important for the court. If one of the parties presents its arguments at a preliminary hearing, then the opposite party is obliged to give a detailed answer to all the facts that were presented by the other party. If the information was not provided, the facts that were stated by one of the parties will be accepted by the court as reliable.

In practice, a preliminary hearing is held no earlier than 4 months after the registration of the claim/complaint in the patent court. The duration of the procedure depends on the category of the case. If the judicial board dealing with this category of cases has a large number of claims/complaints received, then in this case the first stage of the trial may last up to 15 months (Stefan, Tkachev, 2013, p. 45).

Based on the versions set out by the participants in the process, the judge-rapporteur displays all aspects in a written vote. Persons who are members of the same Senate, after the judge-rapporteur, also get acquainted with the case materials.

After reviewing the information, the judges express their opinion on the issue studied, which in most cases is in writing.

According to German law, the judge has the right to make decisions immediately after the preliminary hearing, but most often the court sets a date for the announcement of the decision.

The decision on the date of the trial is made by the presiding judge. He also decides in what form the proceedings will take place: in the form of a meeting or oral proceedings. Often, the trial is held 2-6 weeks after the hearing (Stefan, Tkachev, 2013, p. 45).

At the trial, the plaintiff and the defendant no longer have the opportunity to independently present any facts, but they can make arguments on legal issues, for example, the scope of protection of the intellectual property claim. The Court, on its own initiative, may request additional information if the issue remains controversial. Also, additional evidence must be taken into account by the court if a witness is involved in the process. The witness has the right to provide new evidence during the trial. If the judge needs additional time to analyze new facts provided during the trial, the trial is postponed. During the patent proceedings in the Federal Patent Court, a judicial expert may be involved. They resort to his help in complex technical issues. In practice, due to the constant occurrence of new circumstances, the trial can last up to 4 years. As a rule, only the opinion of a forensic expert is expected by the court for 12 months. 


\subsection{Validity of the Patent}

In most cases, a claim for the invalidity of a patent gets to the Federal Patent Court after the decision of the land Court on the claim for patent infringement. The Civil Rights Court is not authorized to resolve issues concerning the validity of a patent if the Federal Patent Court has not yet made its decision, and the plaintiff has no right to question the validity of the patent in this lawsuit.

In this case, the plaintiff cannot file a claim for the validity of the patent with this judicial authority without passing a court session in the Federal Patent Court. Only upon the outcome of a positive trial in the Federal Patent Court, an objection to the validity of a patent can be considered in civil proceedings. If, at the time of civil proceedings, the claim that was sent earlier to the Federal Patent Court on the invalidity of the patent has not yet been considered, the judge of the civil court has the right to grant the request for suspension of proceedings before the decision of the patent court.

The process of invalidation of a patent is possible if the filing of claims to a lower court has been exhausted, and all claims that were in the proceedings have been considered ${ }^{7}$.

If the claim for violation is not terminated, the judges make a written decision, as a rule, four times (up to ten weeks after the main oral hearing, at which the trial in the first instance ends).

Unlike the objection process, the plaintiff in the case of invalidation of the patent has the right to withdraw his claim at any time at his discretion. A patent is invalidated from the moment of its issuance if the Federal Patent Court has declared it invalid.

The Senate's determination of the validity of patents in most cases takes place in the form of oral proceedings. The exception is the moment when the defendant, to whom the statement of claim was sent, does not provide a report within 1 month $^{8}$.

The parties know the outcome of the process in advance, since before the oral proceedings, based on the provisions of the Patent Law, the Senate on the validity of Patents submits a written opinion, which is preliminary ${ }^{9}$.

At the oral proceedings, the parties have the right to defend their point of view. Before the Senate makes a decision, the participants in the process and the Senate discuss the most important issues, as a result of which a decision is made. As practice shows, the parties often replay the whole process during the discussion. This happens at the moment when the participants in the process understand that the decision will not be made in their favor.

The Senate makes the decision independently and justifies it in writing, after which it sends it to the parties to the process. The announcement of the decision takes place either on the same day, or at a separate meeting.

The senates for consideration of cases on the validity of a patent make judicial decisions.

Under these conditions, the plaintiff takes a more advantageous position, since the decision is made on the basis of the information set out in the claim. If, in the opinion of the court, the fact of the invalidity of the patent is logically stated, then a court decision is made in favor of the plaintiff. Before making a final court decision, the Senate familiarizes the parties with an interim (preliminary) decision.

Based on the results of the decision on the recognition of a patent as infringed, in most cases it is later annulled by the patent court. A person who filed a claim for patent infringement in the land court automatically becomes a defendant in a claim for invalidity in the patent court. There are 29 collegiums in the structure of the Federal Patent Court of Germany. Of these, to date, there are 13 technical appeal boards, the focus of which is focused on appeals during the process of issuing or opposing a patent. The competence of the annulment boards numbered 1,2, 3, 4 includes issues related to the decision on the

\footnotetext{
${ }^{7} \S 81$. The Patent Act of the Federal Republic of Germany (Patentgesetz - PatG) of December 16, 1980, which entered into force on January 1, 1981 with amendments and additions 1986, 1990, 1991, 1992, 1993, 1994,1995 gg http://www.gesetze-im-internet.de/ (date of application 25.08.2021)

${ }^{8} \S 82$. The Patent Act of the Federal Republic of Germany (Patentgesetz - PatG) of December 16, 1980, which entered into force on January 1, 1981 with amendments and additions 1986, 1990, 1991, 1992, 1993, 1994,1995 gg http://www.gesetze-im-internet.de/ (date of application 25.08.2021)

${ }^{9} \S 83$. The Patent Act of the Federal Republic of Germany (Patentgesetz - PatG) of December 16, 1980, which entered into force on January 1, 1981 with amendments and additions 1986, 1990, 1991, 1992, 1993, 1994,1995 gg http://www.gesetze-im-internet.de/ (date of application 25.08.2021)
} 
recognition of a patent as invalid. These boards consist of 4 judges: 3 technical specialists and 1 judgelawyer.

Depending on their decision, the patent may be revoked or restricted. Thus, the Federal Patent Court may perform the following actions in relation to the annulment of a patent: complete annulment of a patent, partial annulment of a patent, clarification of a patent, rejection of a claim for annulment.

\section{CONCLUSION}

From the above, it follows that before filing a claim for the invalidity of a patent, it is necessary to go through the claims review process, that is, the first prevails over the second. The process of considering patent validity cases in the Federal Patent Court is similar to civil procedure. Thus, the process itself in the patent court resembles a civil procedural trial in absentia.

The party interested in the lawsuit files a lawsuit with the Federal Patent Court of Germany on the outcome of consideration of which the court makes a judgment. As mentioned earlier, the defendant has 1 month to provide a response to the statement of claim. It is also possible that the defendant will not provide an answer within the time limit established by law. In this case, the court makes a decision immediately. The reason for this is the fact of failure to provide a response within the time limit established by law.

The results of the authors' work can be further applied in drawing up an educational plan for the next year of work, since studying this topic in higher educational institutions will reduce the number of errors in making decisions and reduce the number of disputes arising with the validity and invalidity of patents.

\section{REFERENCE LIST}

Belozerova, I.I., (2017). Historical and legal analysis of the status of a lawyer in Russia and France. Legal Science and Practice: Bulletin of the Nizhny Novgorod Academy of the Ministry of Internal Affairs of Russia. № 4 (40). file:///C:/Users/lawupupik1/Downloads/Vestnik_40.pdf

Perun, E.D., (2014). Problems of patent rights protection. Problems of modern science and education №2 (20). https://cyberleninka.ru/article/n/problemy-zaschity-patentnyh-prav

Stefan R., Tkachev D., (2013). General aspects of legal proceedings in the field of intellectual property protection in Germany. Journal of the Court of Intellectual Rights. № 1.

http://ipcmagazine.ru/ipcmagazine.local/28 